\title{
GDF2 wt Allele
}

National Cancer Institute

\section{Source}

National Cancer Institute. GDF2 wt Allele. NCI Thesaurus. Code C126996.

Human GDF2 wild-type allele is located in the vicinity of $10 q 11.22$ and is approximately 5 $\mathrm{kb}$ in length. This allele, which encodes growth/differentiation factor 2 protein, plays a role in angiogenesis regulation. Mutation of the gene is associated with hereditary hemorrhagic telangiectasia type 5 . 